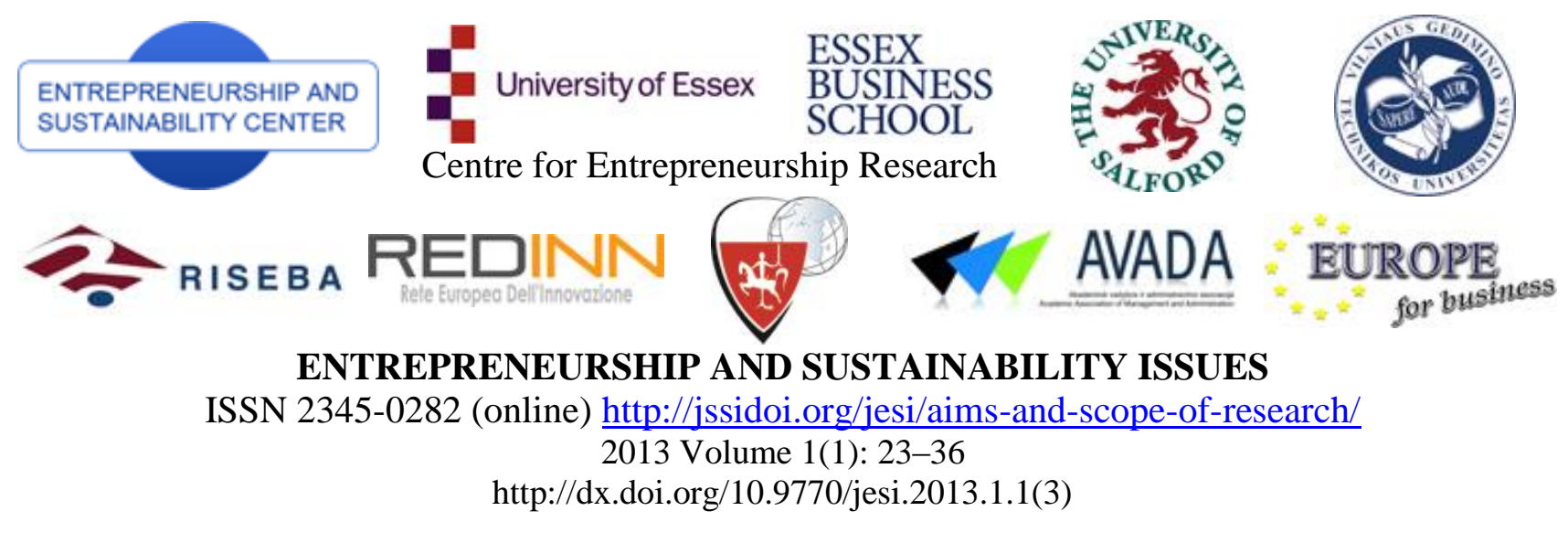

\title{
PHILOSOPHICAL, LEGAL AND GENERAL THEORETICAL ISSUES OF LEGAL LIABILITY
}

\author{
Aleksandrs Baikovs', Ivars Zariņš² \\ ${ }^{1}$ Daugavpils University \\ Vienibas Str. 13, LV-5400 Daugavpils, Latvia \\ ${ }^{2}$ University Turiba, Graudu Str. 68, LV-1058 Riga, Latvia \\ E-mails: ${ }^{1}$ aleks_baikov@inbox.lv; ${ }^{2}$ ivars@orions.lv
}

Received 8 March 2013; accepted 27 July 2013

\begin{abstract}
Traditionally idea of legal liability is limited with the past actions, so called negative liability. Even variety of ideas and tractates can be seen at the supporters of this approach. In the same time amount of studies of the positive liability is growing within recent decades. Even more - scientists have announced that the liability can be only positive and that the protection of subjective rights and legal interest is performed by means of state enforcement. In this article theory and conception found in scientific literature of the legal liability and that interprets it both positively and negatively is critically analysed as well as objective and psychologically - subjective base of legal liability is being researched and on such basis understanding of legal liability will be established. Specific indications will be separated; the totality and forms of implementation will be fortified.
\end{abstract}

Keywords: Social liability, legal liability, negative (retrospective) legal liability, positive (prospective) legal liability, forms of implementation of legal liability, public relations.

Reference to this paper should be made as follows: Baikovs, A.; Zariņš, I. 2013. Philosophical, legal and general theoretical issues of legal liability, Journal of Entrepreneurship and Sustainability Issues 1(1): 23-36.

http://dx.doi.org/10.9770/jesi.2013.1.1(3)

JEL Classifications: K1, K10, K40, K42.

\section{Introduction}

The progressive development of society persistently requires a comprehensive approach to solving a number of pressing issues of the present time. Among them the problem of mainstreaming the personal factor based on the expansion and enrichment of the social relations of a human being and society, which, in turn, stipulate enhancing the role of personality, different kind of social formations (societies, personnel' teams), holds a specific place and, consequently, their social liability to the society in all spheres of social life, as well as of the society before them. In this regard, the search of the most effective ways and sufficient means of adequate formation of a responsible approach to the business put into a person's hands, research related to defining the nature and manifestation of social features (including legal) of liability in reality both in the regulatory and structural and functional aspects thereof.

The laws governing the market economy urge to provide growing of the regulatory role of law in the vital activities of the society by expanding the discretionary management, providing for maximization for an individual, the subjects obtaining a special legal personality of the options of individual self-regulation of 
their social activity. The latter becomes an indicator of liability for the selection of such a manner of putting into effect the objective social needs perceived by the personality as own needs.

The search for new solutions in view of the actualization of certain phenomena of social reality not only leads to differentiation, but also to the integration of scientific knowledge. These processes quite perfectly are reviewed when applicable to the issue of liability, which lately has become to be of a multi-disciplinary nature out of the problem being mainly of a legal nature. This is explained by the fact that the liability entails an extremely wide range of phenomena and acts in all spheres and areas of human activities where there is the need for harmonization of social, collective and individual interests, to keep all those involved in the social relationship within a reasonable, compromise and positive behavior. Now representatives of many sciences, who are aware of social disadvantage in all spheres of public relations regulated, among the number, with the help of liability are interested in the issue of liability (Agejeva 1990). Moreover, each of them in the general scientific object of cognition singled out own object of the research (legal, moral, political liability) taking into account the presence of both specific and general indications being common to all types of liability. In this regard, both identification of individual types of liability with its own nature (social liability) and opposition thereof are obviously inadmissible, which sometimes takes place in the legal literature (Sapun 1982). As was fairly marked by Halfina (1974) “... in recent years, there are made attempts to construe the term (liability - A.B.) in terms of its philological value." In law, she wrote later, this term has acquired a well-defined content, distinct from commonly understood. In the opinion of Halfina (1974) the significance and meaning of this concept lies in negative consequences that occur for a person who committed any unlawful act. Hence, according to her it follows that the liability - has nothing to do with understanding of the commonly used special term (Halfina 1974). It is clear that the use of the term "liability" in its ordinary sense is not sufficient. But numerous attempts taken in the science to develop the scientific definition for the liability, give evidence to the ambiguity of the term and multi-dimensional and many-sidedness of the problem of liability. Clear evidence thereto is different "content" and the use of the term "liability" to describe various aspects, the sides of conduct of any subjects and a variety of phenomena, even within the limits of one of the sciences (philosophy, sociology, psychology, law, etc.)

One can not fail to note that the research of liability in terms of freedom and necessity, the correlation of the concept of liability and multifaceted interpretation of social freedom, the internal duty, the moral law, discharge of duties to the society is common in philosophy.

\section{The objective aspect of legal liability}

The emergence of liability as a social phenomenon follows from the need to cover the general rule of repeated acts of production on daily basis, distribution and exchange of products and to take care that an individual would be submitted to the general terms and conditions of production and exchange. Social liability - the essence of the element, the side of social relationship based on social norms relative to enjoyment of the opportunities corroborated therein and the ought (considered both in terms of personal attitude of a subject to the acts of own conduct and in terms of compliance thereof with their social expectations), between the subjects of liability and any supervisory authority. As one of the forms of manifestation of communication and interdependence of the individual and the society (the individual and collective, the collective and society), which arises objectively in the process of human communication, liability in the society is of a bilateral nature: liability of the individual to the society (the collective) and liability of the society (the collective) to the person performing on the one hand retaining, and on the other the role orienting and stimulating to the social activities being valuable to the public.

It is known that the liability cannot be thought without freedom, just as there can not be freedom without liability. Any free, by its nature act of behavior inevitably raises the question of liability.

Being a public person a human being exists and cognizes the world in the system of particular relations, where his/her position is fixed by the dialectical unity of freedom and necessity. Freedom (freedom of the will as a particular manifestation thereof in terms of specific social organization) is in the cognition of the laws of nature and society, enabling purposeful use of it in practice, in the ability to make decisions competently. Freedom is defined and assessed (in terms of its level), through necessity. The need for acting as the tendency of the development of the heart of the matter, represents the compliance with law, objectively stipulated in the chain of cause and effect relationship of the development thereof, being the most material connexity of phenomena. It (the need) conditions or defines not only the activity itself and also the range of opportunities, which is given in a specific situation. Ultimately, the need is determined by free choice of a particular behavior. At the same time, it should be taken into account that freedom - is not a passive impression of reality reflecting the contemplative attitude of the people to any event. On the 
contrary, freedom gives rise to self-determination of individuals, their cognitive activity arming the subjects of the action with the knowledge of objective necessity, and thereby providing them with the necessary (in terms of their position in the structure of social relations, needs and objectives of activity) the means to use the acquired knowledge in their substantive-realizable activity. In other words, if the theoretical and intellectual level of freedom consists in the possibility of cognizing the world, as well as its continuation is specified in the freedom of conscious choice, then at a practical level - in activity (provided the appropriate means available) putting into effect this knowledge taking the account of the aims set by the subject, the setting whereof is the result of awareness of the specific needs. Thus, the freedom contains within itself the need in a "shot" form.

Value categories of freedom and necessity can be represented as a dialectical unity (the dependence on the one hand and the relative independence - on the other hand, from each other) of these two opposites. Therefore, if it is true that activity of the subject is determined by an objective necessity, it is also true that to a large extent it is determined by his consciousness and will. Conscious goal-setting activities of the people dictated by the cash needs, without abrogating (and not substituting in the mind) the objective regularity of development (the need) may use them in the most effective way within the certain limits, choosing the most optimal ways and means of solving the problems facing them in a particular situation, i.e. to dominate over the need and itself. Only in this event, human activity is free, and is not only of the desired nature. In this regard there appears and gets its methodological basis the problem of enhancing an individual directing and promoting his/her social and helpful behavior, which seems to mediate the recognized necessity, complies with it and in this regard is the factor of accelerating the development of the processes occurring in reality.

In any society, the need for an objective necessity is expressed in the form of specific rules of behavior, accumulating the accrued experience of social interaction, taking into account the specific conditions of a normal human life and society. In changing these conditions and, according to them, the rules of conduct, the society is given the opportunity to deliberate modification of the need by creating new necessities, the necessities of any other order.

Turning of the need for freedom takes place in a circular motion, breaking up into two stages: first, the transformation of "things in themselves" into the "thing for us," i.e., transformation of the necessary as the objective category into the element of consciousness, or otherwise the subjective category forming a mental image (model) of practice, and thereby determining the content and direction of development and, secondly, the return of the ideal-subjective substance in the objective category, i.e. materialization of the earlier specified model of behavior in particular activities. Nodal points of this process are: the necessity - the need the interests - realization of the interests - practice - freedom.

Freedom - the concept, which the object is determined by many factors of the historical development of a particular society. Just in this context, people talk about the level of attained freedom, implying by it the ability to commit a conscious choice based on the cognition and in accordance with the objective necessity. Assessment of this choice just represents the liability. Thereby, freedom is the condition of liability.

The dialectical nature of the relationship between freedom and necessity derives its concretized expression in a relationship of liability. The liability, as an objective attitude of the individual to the society (the collective) as well as of the society (the collective) to the individual, is reflected in the content of his/her consciousness, just as in the content of social consciousness and, therefore, becomes a subjective quality, an element of personal/social (collective, group) consciousness. A person's ability to value the significance and consequences of actions committed by the person, the existence of a liability as an internal incentive to socially useful activity, characterized by the level of activity and initiatives in the implementation of what is possible and appropriate is connected just with the consciousness. In this regard, it is necessary to draw attention to the substance of liability, both in objective and subjective terms, which are as if the continuation of, the development of the same name of its premises (the foundations), moreover, that neither the subject, nor the controlling authority were not adequately able to take into account the actual relation of objective and subjective in their choice (Chermenina 1965).

The objective basis (or assumptions) for liability are: first, the inclusion of the subject of liability in a system of social relations, his/her role and place in the system of social relations of the society, not only the determinative orientability, and also the limits and the opportunity for making free and conscious choice of a particular variant of the behavior and its smooth, initiative implementation, mediating expedient communication of public (collective, group) and personal interests, or who prefer the satisfaction of personal interests to the detriment of the public; and secondly, the presence of social norms that fix the original and the basic position of the individual, and his/her particular situational position in the relationship with the collective, society, another social community. Affirming the social nature of a human being (as a product of social relations in the framework whereof it is integrated), however, it is not possible to state that the 
formation of his/her responsible behavior is to the full extent the result of the impact only on the personality of the world around him. Equally with the determining value of the role of external (objective in relation to a human being) factors of behavior, internal (subjective) factors acting in indissoluble unity with the objective factors play an important role.

Speaking of freedom, in the philosophical literature it is distinguished the freedom of conscience, understood as the possibility and the ability of cognizing laws existing in a society (objective necessity), that is "Theoretical mastery" by them in a perfectly subjective form and the freedom of practice, free will and free choice (Maneshin 1984). The dynamics of the movement from freedom of consciousness to the free will and from it to the freedom of choice characterizes as if the specification (phased development of a subjective basis) of liability to incarnation thereof as a result and, consequently, in the subjective content of liability. As the elements that make up the contents of liability in subjective terms, in our opinion, should also be included: the ability of an individual to assess own actions in accordance with the interests of the society (Panov, Shabalin 1976) and others, his desire for self-fulfillment, self-realization in the objective world (Mislivchenko 1972), the ability of the subject to anticipate the results of own behavior and the willingness to accept (being subject to) assessment. These of traits personality, where the intellectual beginning prevails, are necessarily linked in the subjective content of the liability with components of the mental order, such as motivation, setting, etc.

What components of the content of liability should be included in the objective basis of liability? First of all, we should note that in the philosophical literature, the objective aspect of liability is often identified with own assumptions, or is characterized as its structure. Some authors specify the following to be the elements of this structure: the subject of liability, which shows "who is responsible", the object of liability that characterizes "what he/she is responsible for", the authority specifying "before whom to be accountable" (Panov, Shabalin 1976; Jakovlev 1975). According to others it is required to discern the following in the structure of liability: the subject of liability, his/her social significance of the behavior, the object of liability penalty. At the same time we shall note that it is hardly justified to specify sanctions (as well as to use this term applicable to social liability), in lieu of or in the same conceptual row with the controlling authority (Sapun 1982) as saying about it, we for sure mean not only before whom the subject bears liability and the measure of his liability and the form, the measure of his/her liability (as well as to what extent he/she is responsible), insofar equally with making the control, with the use of appropriate injunction, when necessary, the functional role of the controlling authority lies in this with respect to liability. Moreover, it should be noted that the structure - is the external form of the content. Therefore, it is difficult to agree with the inclusion of liability and supervisory authority into the content. Otherwise, in our opinion, is not consistent with the notion of "content" either in philosophy or in law. It seems more correct to speak of the mechanism, or better - of the system of implementation of the liability.

Continuing review of views on the structure of liability, it is impossible not to draw attention to Plahotnij (1972) point of view that represents it being composed of: socially significant behavior of the individual, free will, measures of social pressure applicable to the personality. Multilateral, multi-pronged approach to the issue of the structure of legal liability shows a number of works of scientists being lawyers. In particular, Chernih (1981) writes on a static, dynamic, attribute and functional structures, which are considered by him as a system of interrelated elements. Revealing the contents of a static structure, he singles out liability for responsible decisions made by the subject, for the committed acts and consequences thereof, in the dynamic structure - the establishment, implementation and consequences of exercising liability; in the attributive structure - both positive and negative liability; in the functional structure - ensuring the qualitative behavior of the subject of liability, the impact on him upon culpable, misconduct (we would add - upon the socially beneficial behavior exceeding the regulatory level), the prevention and bringing up (Chernih 1981).

Analysis of the content of liability (in the unity of objective and subjective) as structurally complex circuit elements (levels) of its consistent implementation is noteworthy as well. Here the following levels are singled out: cognitive, assuming liability for the correct definition of a progressive and objective necessity, axiological level - responsible for the proper assessment of the existing opportunities for actions in accordance with the need for socio-reasoned selection of the alternative behaviors; instrumental and correction level - responsible for the correct choice of the means, methods of implementation of objective necessity, liability for the volitional activity, for strong and the weak will; practical level - responsible for the results of practical actions that implement the requirements of objective necessity.

Prerequisites of social liability and their elements get their specific expression, entering into the operation of the system of putting into effect the liability, which we consider below, paying a special attention to the fact that characterizes it as an objective attitude. 
As noted earlier, the laws of social development have a tendency for expression thereof in the form of a certain kind of requirements (social norms), addressed to members of the relevant social organization (the controlling authority), which serves not only as the subject of cognition of processes and phenomena of the objective reality, and also as the subject of organizing their conscious use in order to ensure social progress and all-round self-realization of the intrinsic qualities of individuals, determining the scope of possible and proper behavior (i.e., the subject of rulemaking).

The social norm - it is usually obligatory social and valuable and in this regard, significant behavior established by the relevant organization (agency), or arisen on the basis of recurring relationships between people and aimed at regulating the social relations, expressing the will of the people dependent upon the level of material development of the society and provided by the measures social influence or public coercion (Kulazhnikov, Shepelev 1985).

The meaning and the main purpose of social norms is that, on the one hand, to ensure a state of dynamic equilibrium of vital activity of the society (another social community), the conditions for all-round, harmonious development of the members of the society and, on the other - to make an active contribution to the progressive processes, solving actual problems of the development of the society, altering the ratio of the possible and appropriate, thus opening the ways for the emergence and development of new objective laws of social development.

In the social norms (legal and illegal) by way of fixing the basic "powerful" lines of interconnections and interdependencies, it is determined position of the subject in his/her relations with the society, collective, another social community (by the controlling authority and the subject of law-making), as well as with other people. The content of these relations is determined by the requirements dictated by the objective reality as a whole, and a particular situation imposed on the behavior of the subject. In other words, the objective content of liability lies in quantity and quality of work, extent and direction of activity subject required by the situation (Kulazhnikov and Shepelev 1985).

Singling out in the system of implementation of liability, above all, the relationship, "the controlling authority - the subject of liability," which has in the initial item of the development the objective (as an appropriate setting), and at the final destination - the subjective (such as awareness by the subject of the standard conduct dictated by objective necessity) nature mediated by the content of social norms, it should be noted that these (social norms) establish not only the nature of their relationship, but also the social conditions (the conditions) and the model of motivational content, which expresses the relationship of social and psychological factors: needs, interest, goals, values, settings of the required behavior. So, through these social and psychological factors the social norm affects the selection of useful and social alternate behavior. Thus, the relationship of "controlling authority - the subject of liability" is the process, within which course there takes place the transfer of objective requirements of social norms in the structure of consciousness with the help of a psychological mechanism.

The relationship of liability for sure exist independently of the fact of awareness by the personality as own personal liability to the controlling authority. As noted by B.S. Jakovlev (1975), different forms of accountability: political, legal and others exist as an objective relationship. But in the case of understanding thereof, the objective relationship of liability continue to exist not only in this capacity, but also as quality of the individual, allowing for the selection of their behavior taking into account the consequences thereof for other members of the relationship. This quality, depending upon the specific rules and the regulated relationships can be both moral and legal. In this context, hardly sufficiently is justified the idea that bringing up of liability in the individual implies its moral liability only, regardless of the specific scope of his/her activities (Jakovlev 1975).

Further movement of the relations of liability is aimed at putting into effect their practical act of responsible behavior and represents the process of objectification of the subjective. Applicable to the legal norms the process of transfer of legal requirements that have become the elements of judicial awareness, in the conscious activity of the individual develops, passing the following stages: awareness of the law in the unity of legal knowledge, evaluative attitude to law and readiness for legal activities) - encouraging (in the form of legal motives) - and duly ordered and directed lawful conduct (Oksamitnij 1985). The latter often depends upon whether the person had sufficient means in this situation for putting into effect the requirements of social norms. It is clear that in determining the proper scope of duties and setting what is possible, the controlling authority is obliged to ensure implementation thereof. In this regard, at this stage of the development of relations of liability it is expedient to envisage the possibility of applying injunction that comply with its normal pattern of the behavior, distinctive of the means of controls and used on the basis of information obtained in the course of monitoring the behavior of the subject. 
Along with the earlier specified means the socially beneficial behavior, controllability and accountability and encouragement (as well as the deprivation or restriction in the use of certain subjective "rights") of the subject of liability have a useful influence on the result, i.e. response of the controlling authority (methods how to ensure the responsible behavior of the objective order), the willingness to undergo evaluation by the supervising authority (the factor of subjective order).

Correlating a particular act of behavior with a "model" behavior established by the regulations, the controlling authority gives assessment thereof. In this case the compliance of the real behavior with the desired social norm of behavior characterizes the latter as a socially-useful and therefore responsible, where the liability is manifested in its active form. Establishment of inconsistency thereof leads to negative liability which ultimately materializes for any adverse consequences for the individual, i.e. punishment. In active (positive, prospective) liability essential personality traits are disclosed the most realistic: the ability to enjoy the freedom of will, activity and initiative to use the opportunities granted for comprehensive development, non-abuse of the subjective rights, knowingly and voluntarily performing the duties imposed on the person.

Coordinated interaction of the elements of the objective side of liability, to which we include: rules controllability or accountability - the action of injunction or security of responsible behavior - exposure to the assessment - social and active behavior - assessment - response of the controlling authority (encouragement or denial of promotion/impairment or depreciation/ in exercising the subjective "rights") encouraging to committing certain behavioral acts by the needs and subjective, where a person defines the principles and forms of own activities, stipulates the specific content of liability.

Major scientists who study this problem point out to these two internally interacted sides of liability.

\section{Legal liability as a subjective - psychological category}

The presence of objective and subjective sides in the content of liability determines the peculiarities of its formation as well. A determining influence on the formation of liability of a personality is exerted by a social reality, which finds its manifestation in corresponding norms. At the same time, in the process of "assimilation" of the content of legal rules by a personality, the code of behaviour contained in the legal rules gets deflected in the system of social and psychological factors of the personality and thereby exert a regulative influence on the personality's activity. As Lukasheva (1973) mentions "the process of implementation of a legal rule is the interaction of its demands and consciousness of an individual."

From the point of view of its subjective and psychological content, liability appears as a unique state of individual consciousness (Anisimov 1979), where in a varying degree depending upon the deepness of cognition, breadth of theoretical assimilation of the social code demands, the movement of the entire system of implementation of liability is reflected sequentially. Therefore, the issue on liability in whole and on positive liability in particular is urgent, conditional upon a conscious assumption that the subject of liability is aware of the content of the requirements necessary in a given situation of social norms, since otherwise even at a formal coincidence the conformity of actual behaviour to the criterion one, the freedom of will and the liberty of choice are out of the question, because the subject does not face a dilemma whether to follow the ordinance of such norms or to choose another behaviour options. It stands to reason that the wider the borders of the freedom of will, of liberty of choice are the higher is the level of social activity, as well as the degree of the impersonating such activity positive liability. "If freedom means the liberty of choice, then liability, - writes Smirnov (1973) - is the assessment of choice of a decision, a deed, the assessment of benefit or harm thereof for the society. To be responsible means to forecast the consequences of own actions, to be guided in own deeds by quite definite motives, for which the person is ready to be responsible vis-à-vis the society ..." (Smirnov 1973).

Objective opportunities of a free choice of a particular behaviour option, and as a result, the degree of liability of a personality depends upon his /her social role and place in the system of social relationship of the society, of other social medium. The criteria of fulfilment by a personality of his/her social role and of determination of the level of his /her liability are the expectations set by the society to the personality. They, as a model of behaviour, are fixed in corresponding rules and in reference to a personality have an objective character. In subjective terms a social role of a personality is manifested in its specific dynamic state - selfcomprehension, which stems from the accentuation of own spiritual essence, of own "ego" from a definite human community, and characterizing a subjective and psychological attitude of the personality towards the society, effective rules, other people. Self-comprehension fulfils a number of interdependent functions, among which they usually mention self-cognition, self-esteem, self-control, self-regulation of behaviour of a personality (Panov, Shabalin 1976). 
It is commonly known that any act of volitional behaviour as the source of its movement has a corresponding need and is formed on its base and serves to satisfy such a need. Exactly they determine the motivating meaning of social norms. According to Uznadze (1966) "where there are no needs, any activity is out of the question as well" and, consequently, the same refers to positive liability as well, since the activity serves as the main criterion of its manifestation.

Having consciousness and will, which is identified as a thinking activity (the brain's function), as a psychological state (an attribute of a personality), as an ability of a person to make decisions and enforce thereof (Panov, Shabalin 1976), a person gets a possibility to control his needs. The said ability finds its manifestation in a motive. As an element of the subjective and psychological side of liability such a motive represents a relatively independent factor of movement, which both in the sense - bearing and functional aspects is connected with the satisfaction of needs of a personality. A motive of a particular behaviour is identified as an evaluating "attitude of a person from a perspective of immediate needs towards the situation", i.e., "on one hand, immediate needs, but on the other hand - attitude towards to the situation of satisfaction thereof" are synthesized in the motive of behaviour (Nurpeisov 1984).

Having an immediate waiting for its satisfaction need, a personality evaluates a social norm, which describes the nature of the required behaviour from a perspective of this need. Such evaluation results in the formation of a corresponding attitude towards the norm, inducing either to follow it or resist it, i.e., to evaluate and, according to the evaluation, act on the upside and the downside. In this way happens the formation of the motive as the incentive to definite targets and practical activity on the achievement of such targets (Jakovlev 1975). Under the influence of a motive in consciousness of a personality there forms a model of a future behaviour, which initially is identified by the subject in the most general terms. The developed model is preceded by setting up a target, which prototype is fixed in social norms. The main moments of the future activity are fixed in the target. The final construction of a model of behaviour is connected with the identification of methods chosen by the subject for the achievement of the target or targets of his/ her activity. By implementing the target setting, where the pre-emptive reflection of a future situation takes place, the person develops a set to a definite behaviour. The content of the set is determined by the personality's targets in a dialectical connection with his /her needs; again, it determines the readiness of the personality to realize his /her actions, subject to control, assessment on the part of supervisory authorities.

A generic term with reference to legal liability is social liability. Their dialectical interrelation is described as a correlation of general (social liability) and of particular (legal liability), as a correlation of a class and kind. To the extent that the general exists and is manifested through a particular, but at the same time is not completed with the latter, the common attributes and patterns, the forms of implementation intrinsic to social liability inevitably find their manifestation in legal liability and individual types thereof. Addressing the problem in social liability in the course of study of legal liability by virtue of the fact that only such approach implies the formation of methodological preconditions for studying this important social phenomenon.

\section{Conceptual approaches to the characteristics of legal liability}

Basically, social liability represents the relationship between a personality and the society, which takes the form of a system of mutually corresponding to each other rights and obligations on the observance of social norms, which fulfilment implicates approval, but behaviour inconsistent with the model rooted in them, as well as non-fulfilment - creation of obligation to endure unfavourable consequences of the behaviour deflected from the pattern established in the rule of law.

Traditionally legal liability is used to be considered as liability for the past, as negative liability. "Legal liability - wrote Samoschenko and Fakurshin (1971) - since the time, when it appeared, always used to be a liability for the past, for the committed delinquent behaviour." Or, for example, Rebane (1987) asserts: a legal liability is by all means retrospective, this is a liability for an offence. Many scientists maintain this point of view even today. From the perspective of understanding of legal liability exclusively as a liability for the actions committed, a considerable interest is represented by a concept of Bratus (1976), who assumed that a liability is a state of compulsion to the performance of an outstanding obligation.

However, one must not forget that the processes of development do not leave also the legalistic notions unchanged, which content undergoes definite qualitative changes, their outward signs and properties are being continuously updated, detailed, i.e., despite their obvious stability and conventionality of understanding and interpretation they are being modified. One of the results of evolution of opinions refers to positive legal liability.

A category of legal liability, which represents one of the specific forms, which has mediated a social liability, exists in two aspects: negative (retrospective) and positive (prospective), which are conceived as 
either independent or interrelated sides of a unified whole (Bestugina 1986), or as an independent phenomenon (Bulatov 1985), or as various forms of its implementation (Kudryavtzev 1986). If the first aspect has been studied quite fully, although a longstanding and continuing up to now discussion has not removed all controversial issues, the second aspect has been studied weaker. A negative aspect, which from the point of view of a classical rendering of legal liability, is completed with its content, which is characterized by the unity of three attributes: state coercion, condemnation of an offender and of an offence, unfavourable consequences and, eventually, reduces to the application with regard to the offender of unfavourable consequences of his/her delinquent behaviour, i.e., negative per se response to the offence committed. To the extent that legal liability (in the negative aspect) is established as a result of a delinquent behaviour, which violates the rights and interests of a third party inflicting to it one or another harm, the application of the establishing norms appears for one of the means of protection and advocacy thereof.

You can't fail to notice the diversity of opinions of advocates of negative (retrospective) liability. According to a number of supporters of such understanding of legal liability, a peculiar feature of this remedy that distinguishes it from other compensatory remedies, lies in the application of coercive measures by the agencies of public authorities, thereby distinguishing it from other compensatory remedies that might be applied to offenders directly by the authorized persons. Meanwhile, a voluntary application of these remedies does not change their nature as the public coercive measures, which content and the order of application is prescribed by law. It is not by chance that legal liability as often as not is considered as the public coercive application of any unfavourable consequences to the offender (Bratus 1976). So, for instance, the authors of one juristic encyclopaedia affirm that legal liability is "the state enforcement to the fulfilment of demands of law, legal relationship, where each of the parties must be accountable for its actions vis-à-vis the other party, the state and the society" (Juristic Encyclopaedia 2000). According to others "legal liability proper is the application of sanctions of law enforcement provisions by a relevant government authority, which is manifested in negative consequences for the offender such as deprivation or limitation of personal or material nature" (Juristic Encyclopaedic Dictionary 2002). For a third party "legal liability is a prescribed by legal provisions obligation of a subject of offence to endure unfavourable consequences" (Large Juristic Dictionary 2004).

The idea of positive liability born in the attempts to cross the strict limits of a normative approach to law, including all possible forms of manifestation of social liability, internally is inhomogeneous: it appears identical to a legal duty, or to demands of legality, or to a statutory duty of a positive nature, or a specific quality of the total (generalized) obligation, or to a category of legal awareness (Bobrova, Zrazhevskaya 1985; Chernih 1981; Matuzov 1987; Rifinyus 1983). An interesting and, at first sight, quite paradoxical idea was uttered by scientists, claiming that legal liability has a positive sign, what witnesses controversy of issues raised.

The quoted views on positive liability could hardly be acknowledged constructive, since voluntarily or involuntarily they lose the specific content of this social and legal phenomenon. According to some authors, polemics on the positive liability issue seems even scholastic (Dontzov 1987).

We presume that legal liability, in general, is a conditioned upon the necessity of attainment of a legally significant result (a target) qualitative characteristics of a legal status and of right - exercising activity of a subject of law (both an individual and a group), which is secured and stimulated (directed by an optimal for the attainment of this result (the target) correlation of subjective rights, statutory duties (powers) and legal prohibitions, which guarantee the necessary selectivity and independence of legal activity of a subject; controlled with respect to legally significant parameters, which express mandatory directions of legal activity with a view to presumptive correction of the said correlation of rights, duties and prohibitions, and judged by the actually attained result in the context of the level, degree of its conformity to the target of a legal regulation, with due account for the subjective and objective opportunities of a subject of law.

For the purposes of the substantiated, pretending somewhat to universality understanding of legal liability, the theoretically possible distinguishing of two aspects thereof is a mere detail: liability in the suggested meaning includes the manifestation of legal activity of subjects of law, which is at all times positive intrinsically, i.e., develops in a positive, regulatory legal relationship. In this regard we share the viewpoint of the authors, who consider a rather entrenched and fairly fundamentally come into research and practice general use concept of the protective legal relationship as untenable (Karpushin, Kurlyandsky 1974) and agree with the viewpoint of the authors of a two-volume book "Legal Framework of Socialism" in that the so-called "protective legal relationship" is differed from the regulatory legal relationship merely by a circumstance that the legal relationship assumes, as a rule, inclusion of additional guarantees of transition of regulatory prescriptions into practice in the course of implementation" (Legal Framework of Socialism... V.2. Functioning and development 1987). 
Essentially, this circumstance does not change and cannot change the regulatory character of this legal relationship, as of any legal relationship in general, which immediate content refers to the exercise of subjective rights and performance of particular obligations by the subjects of law, even though they are offenders, who subjected to particular measures of legal penalty (punishment) and who are at the time of exercise of right under more or less strict control of the public and legal coercion.

A qualitative characteristics of a legal status and the right - exercising activity of such type of subjects, is, surely, kind of specific, thereby, perhaps, justifying, for research, the usage of the term "negative" liability applicable to this characteristics i.e., to liability of the named subjects. But, we can judge on the latter also as on positive, i.e., legal liability in general, again only in the context of the category of a social and legal activity in the right - exercising sphere, which might be identified as "...a voluntary, conscious activity manifested in the interest to law, respect to law, recognition of a high prestige of activity of legal institutions, connected with searching for more efficient ways of application of their powers and implementation of their civil obligations, civic duty in the legal field" (Socialist Way of Life. Public - Legal Problems 1980).

Consequently, underlying the unity of social liability, one should consider the presence of different forms of its implementation. In other words, legal liability is an integral phenomenon, a dialectic unity of liability for actions committed in the past (retrospective liability) and liability for the present and future (positive prospective liability). Initially such understanding of liability was worded in philosophical literature, by mentioning the presence of two abovementioned aspects, which should be considered in unity, in their correlation and interdependence, but reduction thereof to one of them was estimated as inevitable narrowing of the liability notion leading to mistakes (Grossman 1974).

On these grounds, whereas the characteristic features intrinsic to the kind find their manifestation in every type, it cannot be denied that also legal liability by nature has two aspects. The same as social liability it should have both positive and negative aspects. "Only inclusion of both positive and negative aspects into the structure of legal liability, - outlines Chukhvichev (2001) - enables to study it in the general social context and consider as a specific condition of a personality, characterizing, on one part, the person's awareness of his role in legal relationship, but on the other part as a possibility of social influence on the person through law, for the purpose of protection of fundamental social interests. Such approach enables to point up that legal liability represents a necessary tool for achievement of true freedom by a participant of social relations" (Chukhvichev 2001).

Consequently, the logic of the supporters of an exclusively negative aspect of legal liability is vicious from the outset, since it contravenes the requirements of the academic dialectical logic. Understanding of legal liability only in the light of public coercion excludes its objective necessity, as well as law in general, since represents it as violence. The fact that voluntary or involuntary at such approach everyone, save for offenders, is excluded from the scope of legal liability refers to the matter of no little interest as well. At a two-aspect understanding of legal liability it appears as integrated characteristics of a conscious, active attitude of subjects of law towards the entire aggregate of the protected by law interests (social, private, personal) (Luchin 2002). Fairly Strogovich (1979) in a number of dominant traits of legal liability emphasized the exact understanding by a citizen, a civil servant of obligations imposed on them by authority of law, correct attitude towards them, to a person to whom such obligation is owed - society, the state, a third party. It is not least importantly to understand that legal liability exists not only for violation of law, although in such case it is manifested most brightly and clearly. "Legal liability always acts as liability for proper execution of law. And this is not just potential liability for possible violation thereof, not just a sense and awareness of liability, but real liability, real relations within the limits of law" (Nazarov 1981).

Shindyapina (1998) suggests calling the retrospective aspect of liability "legal liability", but the positive one - "legal liability." It appears that such suggestions do not bring anything new since from the grammar viewpoint the differences in this case are not principle. So, for instance, Maleyin (1992) asserted that "punishment is the legal liability understood exactly in the retrospective aspect."

Once a legal rule is a model, a pattern, a benchmark of possible or due behaviour, the regulation of legal liability is implemented by establishing in the legal rules the permissions, obligations and prohibitions to perform or not perform certain actions that manifest the standard of evaluation of good or delinquent behaviour. Establishment in legal rules the statutory (legitimate) legal liability is preceded by any behavioural act. As writes Chernih (1998) the statutory liability is the objectively conditioned, established by law and protected by the state necessity (obligation) of conscious and voluntary fulfilment of legal instructions by the participants of legal relationship. It fulfils a constructive and regulatory function, being the pattern (structure, model) of actually responsible and due behaviour. Accordingly, the positive and negative aspects of implementation of legal liability manifest the attitude of the subjects of law towards the statutory liability. 
The opponents of understanding of legal liability as of an integrated legal formation speak about the merger of two contrary phenomena into one legal notion and to that end about unreasonable duplication of the terminology, which, for example, according to Maleyin (1985) results in that a basically positive legal liability loses concreteness and in fact merges with the notion of law. In this connection it is possible just to mention that the system of legal rules has distinguished long since and expressly the norms that establish legal liability and collectively form the same-name institution. In the same way a number of academic lawyers analogize, according to whom positive liability does not bring anything new if compared to obligation and therefore refers to an artificial structure (Maleyin 1985; Halfina 1974).

According to Leyst (1981) the designation of two different phenomena and relations by one term "liability" generated an idea that positive and negative liability manifests two aspects of one notion. Such idea leads to the attempts to identify the notion in general, where as a result the qualities of positive liability are transferred to legal liability for offence (and vice versa). Thereby, the view of "positive" liability merely as of the other aspect of liability - "negative" is dangerous by unreasonable shift of emphasis" (Leyst 1981).

Of course, identification of positive liability and obligation is at least fanciful and disagrees with the nature of those, although interrelated, but holding different legal nature and playing different roles in the mechanism of legal regulation of legal phenomena. So, legal liability corresponds to a certain subjective right to public support, approval, defence and protection of a corresponding faithful and good practice of a person, acting as dual categories and non-existing independently, apart from each other. But positive liability has only a subjective side.

In logic the term "notion" is revealed as a thought, which generalizes and distinguishes the items of a class according to the general and collectively specific attributes. Consequently, any notion is based on certain attributes crucial for its existence per se. The attributes are to be understood as an exponent, a mark, a sign according to which it is possible to recognize, identify something. Therefore, exactly the attributes refer to the base on which not only the object of study, but, perhaps, its difference from others both similar and nonsimilar objects are constructed. In this connection it is clear why a variety of notions, as well as of definitions of legal liability existed at different times and exists nowadays. A different set of emphasized attributes leads to different results.

By underlying the presence of common signs intrinsic to social liability in general, we can mark specific marks of legal liability. Inter alia: (1) legal liability is based on legal rules that confer to it the certainty and general binding; (2) state guarantee; (3) coverage through public coercion or convincing; (4) legal liability, as the necessary consequences, implies approval or disapproval, award or punishment; (5) legal liability is implemented in a form of action prescribed by the law; (6) legal liability basically is single, but implemented in two different forms (Lipinsky 2004).

\section{Positive liability}

Understanding of positive liability is controversial. Although this issue has been studied for more than forty years, the accord has not been reached yet.

A hypothesis of understanding of legal liability as perception of duty was advanced among the first. So, according to Fatkullin (1987) "positive liability is the perception of legal properties of own activities (omission), correlation thereof with effective laws and bylaws, readiness to be responsible for them vis-à-vis the state and society." As arguments the opponents of this viewpoint for a reason pointed that at such approach the proper legal content is being lost leaving to positive liability just psychological and moral attributes. However, whereas positive liability is bound to a personality and therefore is characterized in the unity of its objective and subjective attributes and properties, it is obvious that such understanding of positive liability caused the studies of one of the sides of this comprehensive legal phenomenon. As often as not the following factors are included with subjective attributes of liability: awareness of legal rules, obligations, development of inner psychic attitude towards them, aspiration to commit certain actions, emotions, motives, targets (Lipinsky 2004).

In an effort to overcome one-sidedness of understanding of positive legal liability caused by the obviously excessive psychologization of this legal phenomenon, at a later stage precisely the opposite approach was formed: research of positive legal liability on the part of objective attributes. In this context a viewpoint of Tarkhov (1973), who considered legal liability as a regulated by law obligation to realize own actions, is indicative. "The demand of realization refers to the main attribute and essence of liability, whether the realization would be followed by disapproval and punishment refers a completely different question." A positive side of this approach lies in the pointing to the obligation. If we talk about the obligation to realize own actions, then positive liability transforms into awareness of duty, i.e., eventually reduces to subjective 
attributes. But if to have in mind a procedural obligation, then it is not absolute, since a person is not obliged to witness against himself. This circumstance quite fairly caught the eye of Leyst (2002). In efforts to overcome this shortcoming the positive liability started to be considered as a variety of obligation, but not reducing exclusively to it, as an obligation to follow legal regulations, an obligation to act in compliance with legal regulations. Such was a view of the problem under consideration expressed by Bazylev (1985) who believed that the essence of positive liability lies in the obligation to follow the prescription of legal rules, which must be implemented in the actually good behaviour. "As follows from its content, legal liability is such a tie, within which limits the state, acting on behalf of society, formulates an abstract obligation of all subjects to perform a particular legal obligation, but by itself acts as a subject entitled to demand the performance of this obligation. Particular obligations of the subjects quasi include a rather broad in terms of scope demand of performance of certain legal obligations and observation of bans."

Strictly speaking, positive liability cannot reduce to legal obligation only. This is a phenomenon of a broader kind. Obligation and liability are, certainly, interrelated, but by means are identical notions. "The notion of liability is broader than just an obligation, this is a legal relationship comprised of several elements, while any legal relationship has, at least, two subjects, whose right and obligation are corresponded to each other" (Kudryavtzev 1986). Liability represents a more capacious and broader notion, than a legal obligation. As ascertained by Matuzov (1987) "... an obligation is a concrete (standardized) form of manifestation of liability." By considering legal liability as a component, as an element of a legal status of a personality and calling it a status liability, Matuzov (1987) understands it liability for proper and correct performance of obligations imposed on the personality. This is "positive liability, i.e., liability for proper performance of obligations, of moral and legal duty" (Matuzov 1987). Mordovets (1996) by supporting in general the idea of status liability, draws attention to the correlation of positive liability and legal duty. It stands to reason that the notion of legal duty is broader than legal obligation. "Duty, - is a sort of an objective obligation. But the notion of obligation, unlike duty, has a more concrete character... Positive liability presumes the independent, fair, active performance of obligation, voluntary abidance to statutory requirements, to principles of law. And in this context the active legal liability as if merges with the legal duty" (Mordovets 1996).

A number of scientists understand the positive legal liability as a real good behaviour of a subject. For instance, according to Tarbagajev (1994) “...criminal liability may not be identified in statutory requirements as acting in a certain manner. The latter is just a legal precondition thereof, in reality is rooted even deeper in real necessity of a subject to fulfil his social role ... Criminal liability is the performance of what is required." The essence of positive liability lies neither in the obligation to abide the law, nor in rights and obligations of citizens and of the state, but in responsible behaviour thereof (Chirkov 1996).

A legal rule establishing the model of socially beneficial and approvable behaviour represents to this effect not just the degree of freedom, but of liability as well. Positive liability is provided for by legal provisions. Therefore, while implementing rights and obligations, a subject of a corresponding legal relationship constantly correlates his behaviour with the model anticipated by the legal rule. Liability in general and legal liability in particular is inconceivable without the obligations established by legal rules. Consolidation thereof in legal rules is the statistics and, accordingly, implementation thereof is the dynamics of legal liability.

It stands for reason that both legally acceptable and delinquent behaviour without a corresponding exemplary, established in a legal rule model, cannot work out. Eventually, the qualification of behaviour as either legally acceptable or delinquent is the statement of conformity or non-conformity of real behaviour to the pattern established by a legal rule; this is the finding of legal facts: either of legally acceptable behaviour or of offence.

The majority of scientists engaged in study of legal liability proceed from the unity of positive and negative, emphasizing the similar-named aspects. But in this way they assert not just the difference, but also the contradiction thereof, thereby subdivide the integrated phenomenon. To this effect the viewpoint of those, who while emphasizing the integrity of legal liability, assert the presence of different forms of implementation, manifestation, at the same time preserving the unity of this phenomenon, appears interesting and more farsighted. For instance, Lipinski (2004) distinguishes two different forms of implementation of legal liability: voluntary and coercive. Nevertheless, the origination of the liability implementation form concept, obviously, should be conferred to Kudryavtzev (1986), who in the published yet in 1986 monograph "Law, Deed, Liability" wrote that "in case of violation of the established rules of behaviour, and, consequently, of demands of the social control another form of liability is implemented - so- called retrospective, negative liability." Kudryavtzev (1986), which found its development in writings of a number of scientists. In particular, Pokhmelkin (1990) asserted that what is "denoted by the terms "positive liability" 
and "retrospective liability" is nothing, but the voluntary and coercive forms of implementation of the integrated legal liability, which acts as the consolidated in the law measure of due behaviour...the form of criminal liability is the method of its implementation in social relationship through the medium of adequate to its demands behaviour of people." To the extent that the provisions related to legal liability refer to an element of the statutory regulation mechanism, it is important to particularize the roots, target, principles and functions of this sophisticated legal phenomenon.

\section{Conclusions}

Legal liability is a conditioned upon the necessity of attainment of a legally significant result (a target) qualitative characteristics of a legal status and of the right - exercising activity of a subject of law (both an individual and a group), which is secured and stimulated (directed by an optimal for the attainment of this result (the target) correlation of subjective rights, statutory duties (powers) and legal prohibitions, which guarantee the necessary selectivity and independence of legal activity of a subject; controlled with respect to legally significant parameters, which express mandatory directions of legal activity with a view to presumptive correction of the said correlation of rights, duties and prohibitions, and judged by the actually attained result in the context of the level, degree of its conformity to the target of a legal regulation, with due account for the subjective and objective opportunities of a subject of law.

Legal liability develops in regulatory legal relationship.

The concept of protective legal relationship seems inconsistent as it does not bring anything fundamentally new in the general characteristics of implementation of legal liability.

Legal liability as an integrated legal phenomenon is implemented in two forms: in negative and positive liability.

\section{References}

Agejeva, E.A. 1990. Juridjicheskaja otvetstvennostj $v$ gosudarstvennom upravlenii (Socialno-pravovoi aspekt). Izdatelstvo Leningradskovo universiteta, Leningrad. 144 p.

Alexeyev, S.S. 1981. Obschaja teorija prava, T.1. Izdatelstvo Juridicheskaja literatura, Moskva. 360 p.

Anisimov, S. 1979. Nravstvennaja svoboda i otvetstvennostj. Aktivnaja zhiznennaja pozicija lichnosti, Politicheskoje samoobrozovanie 11: 95-103.

Bazylev, B.T. 1985. Juridicheskaja otvetstvenostj. Izdatelstvo Krasnojarskovo universiteta, Krasnojarsk. 120 p.

Bestugina, M.A. 1986. Socialjnaja obuslovljennostj i naznachenije grazhdansko-pravovoi otvetstvennostji v sovremennih uslovijah (teoretjicheskij aspekt). Moskva. 24 p.

Bobrova, N.A.; Zrazhevskaja, T.D. 1985. Otvetstvennostj v sistjeme garantjij konstitutsionnih norm (gosudarstvenno-pravovije aspekti). Izdatelstvo Voronjezhskovo universiteta, Voronjezh. $154 \mathrm{p}$.

Bratus, S.N. 1976. Juridicheskaja otvetstvennostj i zakonnostj. Ocherk teorii. Izdatelstvo Juridicheskaja literatura, Moskva. 216 p.

Bulatov, A.S. 1985. Juridicheskaja otvetstvennostj (obscheteoreticheskije problemi): Avtoref.dis...kand. jurid, nauk. Leningrad. 19 p.

Chermenina, A.P. 1965. Problemi otvetstvennosti v sovremennoj burzhuaznoi etike, Voprosi filosofii 2: 76-87.

Chernih, E.V. 1981. Problema pravovoi otvetstvennosti v uslovijah razvotovo socialisticheskovo obschestva (Voprosi teorii): Avtoref.dis...kand.jurid.nauk, Saratov. 23 p.

Chernih, E.V. 1998. O normativnom haraktere juridicheskoi otvetstvennosti, Voprosi teorii gosudarstva i prava 1(10): 80-83.

Chirkov, A.P. 1996. Otvetstvennostj v sisteme prava/Uchebnoje posobije. Izdateljstvo Kaliningradskovo universiteta, Kaliningrad. 77 p.

Chukhvichev, D.V. 2001. Svoboda i pravo: Avtoref.dis...kand.jurid.nauk, Moskva. 22 p.

Dontzov, S.E. 1987. Socialjnaja spravedljivostj i primenjenije imuschestvennoi otvetstvennosti. O roli juridicheskoi otvetstvennosti v uslovijah uskorenija socialjno-ekonomicheskovo pazvitjija, Uchonije zapiski TGU, Trudi po pravovedeniju 765: 94-104.

Fatkullin, F.N. 1987. Problemi teorii gosudarstva i prava: Kurs lekcij. Izdatelstvo Kazanskovo universiteta, Kazan. 336 p. 
Grossman, H. 1974. Svoboda i otvetstvennostj. Filosofskije problemi obschestvennovo razvitija. Izdatelstvo Mislj, Moskva, $140-147$.

Halfina, N.O. 1974. Obscheje uchenije o pravootnoshenii. Juridicheskaja literatura, Moskva. 340 p.

Jakovlev, B.S. 1975. Otvetstvennostj kak faktor reguljatsii povedenija lichnosti, Nauchnoje upravljenije obschestvom 9: 107-145.

Juristic Encyclopaedia [Juridicheskaja enciklopēdija]. 2000. (red. Tihomirov M.U.) 5-e izd., pererab.i dop., Izdanije Tihomirova M.U., Moskva. 972 p.

Juristic Encyclopaedic Dictionary [Juridicheskij enciklopedicheskij slovarj]. 2002. (red. Kutafin O.E.). Nauchnoje izdatelstvo Boljshaja Rossiiskaja enciklopedija, Moskva. 558 p.

Karpushin, M.L.; Kurlandskij, V.I. 1974. Ugolovnaja otvetstvennostj i sostav prestupljenija. Izdateljstvo Juridicheskaja literatura, Moskva. 199 p.

Kudryavtzev, V.N. 1986. Zakon, postupok, otvetstvennostj. Izdateljstvo Nauka, Moskva. 448 p.

Kulazhnikov, M.N.; Shepelev, V.I. 1985. Pravo v sisteme norm razvitovo socializma. Izdateljstvo Rostovskovo universiteta, Rostov na Donu. 143 p.

Large Juristic Dictionary [Bolshoj juridicheskij slovarj] 2004. (red. Suharev A.J.; Krutkih V.E.) 2-e izd., pererab.i dop., Izdatelstvo Infra-M, Moskva. 704 p.

Legal Framework of Socialism.... V.2. Functioning and development [Pravovaja sistema socialisma. T.2. Funcionirovanije i razvitije]. 1987. red. Vasiljev A.M. Izdatelstvo Juridicheskaja litetatura, Moskva. 327 p.

Leyst, O.E. 1981. Sankcii i otvetstvennostj po sovetskomu pravu. Izdateljstvo Moskovskovo gosudarstvennovo universiteta, Moskva. $240 \mathrm{p}$.

Leyst, O.E. 2002. Suschnostj prava. Probljemi teorii i filosofii prava. Izdateljstvo IKD Zercalo-M, Moskva. 288 p.

Lipinsky, D.A. 2004. Probljemi juridicheskoj otvetstvennosti. Izdatelstvo Juridicheskij centr Press, Sankt-Peterburg. 409 p.

Luchin, V.O. 2002. Konstitucija Rossiiskoi Federatsii. Problemi realizatsii. Izdatelstvo JUNITI-DANA, Moskva. 687 p.

Lukasheva, E.A. 1973. Socialjistjicheskoje pravosoznajije i zakonnostj, Izdateljstvo Juridicheskaja literatura, Moskva. 343 p.

Maleyin, N.S 1985. Pravonarushenije: ponjatije, prichini, otvetstvennostj. Izdateljstvo Juridicheskaja literatura, Moskva. 192 p.

Maleyin, N.S. 1992. Juridicheskaja otvetstvennostj i spravedlivostj. Izdatelstvo Juridicheskaja literatura, Moskva. 160 p.

Maneshin, V.S. 1984. Distsiplina i obschestvo. Socialno-filosofskij aspekt. Izdatelstvo Moskovskovo gosudarstvennovo universiteta, Moskva. $302 \mathrm{p}$

Matuzov, N.I. 1987. Pravovaja sistema i lichnostj. Izdatelstvo Saratovskovo universiteta, Saratov. 294 p.

Mislivchenko, A.G. 1972. Chelovek kak predmet filosofskovo poznanija. Izdatelstvo Mislj, Moskva. 189 p.

Mordovets, A.S. 1996. Socialno-juridicheskij mehanizm obespechenija prav cheloveka i grazhdanjina. Izdatelstvo SVSh MVD RF, Saratov. 196 p.

Nazarov, B.L. 1981. O juridicheskom aspekte pozitivnoi otvetstvennosti socialnoj otvetstvennosti, Sovetskoje gosudarstvo gosudarstvo i pravo 10: 29-38.

Nurpeisov, E.K. 1984. Psihologija pravomernovo povedenija. Izdatelstvo Nauka KazSSR, Alma-Ata. 127 p.

Oksamitnij, V.V. 1985. Pravomernoje povedenije lichnosti, Izdatelstvo Naukova dumka, Kiev. 176 p.

Panov, A.T.; Shabalin, V.A. 1976. Socialnaja otvetstvennostj ljichnosti v razvitom socialjistjicheskom obschestve. Izdateljstvo Saratovskovo universiteta, Saratov. $141 \mathrm{p}$.

Plahotnij, A.F. 1972. Svoboda i otvetstvennostj (socialogicheskij aspekt problemi). Izdatelstvo Harjkovskovo universiteta, Harjkov.159 p.

Pokhmelkin, V.V. 1990. Socialjnaja spravedljivostj i ugolovnaja otvetstvennostj. Izdateljstvo Krasnojarskovo universiteta, Krasnojarsk. 176 p.

Rebane, I.A. 1987. O metodologicheskih i gnoseologicheskih aspektah uchenija ob osnovanjijah juridicheskoi otvetstvennosti, Uchonije zapiski Tartusskovo un-ta 852: 7-32. 
Rifinyus, V.F. 1983. Otvetstvennostj no trudovomu pravu GDR (sravnjiteljnoje ussledovanije): Avtoref.dis...kand.jurid.nauk, Moskva. 24 p.

Samoschenko, I.S.; Farukshin, M.H. 1971. Otvetstvennostj po sovetskomu zakonodateljstvu. Izdateljstvo Juridicheskaja literatura, Moskva. 240 p.

Sapun, V.A. 1982. Obschesocialjnaja otvetstvennostj i pravovoe reguljirovanjije, Pravovedenjije 3:16-22.

Shindyapina, M.D. 1998. Stadii juridicheskoi otvetstvennosti: Uchebnoje posobije. Izdatelstvo Knizhnij mir, Moskva. 168 p.

Smirnov, G.L. 1973. Sovetskij chelovek. Formirovanjije sociallisticheskovo tipa lichnosti. Izdateljstvo Politizdat, Moskva. 376 p.

Socialist Way of Life. Public - Legal Problems [Socialisticheskij obraz zhizni. Gosudarstvenno pravovije problemi]. 1980. (red. Kazimirchuk V.P). Izdatelstvo Juridicheskaja literatura, Moskva. 232 p.

Strogovich, M.S. 1979. Suschnostj juridicheskoi otvetstvennosti, Sovetskoje gosudarstvo i pravo 5:72-78.

Tarbagajev, A.N. 1994. Otvetstvennostj v ugolovnom prave. Izdateljstvo Krasnojarskovo universiteta, Krasnojarsk. 78 p.

Tarkhov, V.A. 1973. Otvetstvennostj no sovetskomu grazhdanskomu pravu. Izdatelstvo Saratovskovo universiteta, Saratov. 456 p.

Uznadze, D.N. 1966. Psihologicheskije izsledovanjija. Izdatelstvo Nauka, Moskva. 451 p. 